\title{
Fusarium graminearum growth inhibition mechanism using phenolic compounds from Spirulina sp.
}

\author{
Mecanismo de inibição de Fusarium graminearum por compostos fenólicos extraídos de Spirulina sp. \\ Fernanda Arnhold PAGNUSSATT ${ }^{1 \star}$, Larine KUPSKI ${ }^{1}$, Francine Toralles DARLEY ${ }^{1}$, Paula Freitas FILODA ${ }^{1}$, \\ Émerson Medeiros Del PONTE², Jaqueline GARDA-BUFFON ${ }^{1}$, Eliana BADIALE-FURLONG ${ }^{1}$
}

\begin{abstract}
The application of natural antifungal substances is motivated by the need for alternatives to existing methods that are not always applicable, efficient, or that do not pose risk to consumers or the environment. Furthermore, studies on the behaviour of toxigenic species in the presence of natural fungicides have enabled their safe application in the food chain In this study, Spirulina LEB-18 phenolic extract was assessed for its antifungal activity on 12 toxigenic strains of Fusarium graminearum isolated from barley and wheat. The susceptible metabolic pathways were assessed through the determination of structural compounds (glucosamine and ergosterol) and enzyme activity of the microorganisms' primary metabolism. The results indicate that phenolic extracts reduced the growth rate of the toxigenic species investigated. The $\mathrm{IC}_{50}$ was obtained by applying 3 to $8 \%(\mathrm{p} / \mathrm{p})$ of phenolic compounds in relation to the culture medium. The use of this natural fungicide proved promising for the inhibition of fungal multiplication, especially in terms of the inactivation of enzymatic systems (amylase and protease) of Fusarium graminearum.

Keywords: natural antifungal agent; structural compounds; enzymes.

Resumo

A aplicação de substâncias naturais com efeito antifúngico é motivada pela necessidade de alternativas aos métodos existentes que nem sempre são aplicáveis, eficientes ou sem risco de danos ao consumidor ou meio ambiente. Além disso, estudos para elucidar o comportamento de espécies toxigênicas mediante fungicidas naturais tornam-se necessárias, contribuindo dessa forma com a segurança alimentar. Neste trabalho, extrato fenólico de Spirulina foi utilizado para avaliar a atividade antifúngica sobre 12 cepas toxigênicas de Fusarium graminearum, isoladas de cevada e trigo. As rotas metabólicas que poderiam ser afetadas foram avaliadas através da determinação de compostos estruturais (glicosamina e ergosterol) e da atividade de enzimas do metabolismo primário dos micro-organismos. Os resultados indicaram que os extratos fenólicos reduziram a velocidade de crescimento das espécies toxigênicas estudadas. $\mathrm{O} \mathrm{IC}_{50}$ foi obtido na concentração de 3\% a $8 \%$ (p/p) de extrato fenólico. A utilização desse fungicida natural foi promissora para a inibição da multiplicação fúngica, em especial pela inativação dos sistemas enzimáticos (amilase e protease) de Fusarium graminearum.

Palavras-chave: antifúngico natural; compostos estruturais; enzimas.
\end{abstract}

\section{Introduction}

There has been an ongoing search for new solutions for losses caused by fungal contamination during farming, storage, and processing of grains because active agents in fungicides can remain in the environment besides selecting resistant and toxigenic species (DORS et al., 2011; HEIDTMANNBEMVENUTI et al., 2012). One widely-investigated alternative solution to this problem is to search for natural compounds of microbial or vegetable origin with proven antifungal power (VIUDA-MARTOS et al., 2008). Toxigenic fungal species of the Fusarium and Aspergillus families are often used to study the effect of such compounds (ZABKA; PAVELA; GABRIELOVASLEZAKOVA, 2011). The chemical compounds extracted from natural sources with antifungal properties include essential oils, phenolic compounds, and peptides (OLIVEIRA;
BADIALE-FURLONG, 2008; PAGNUSSATT et al., 2012; SOUZA et al., 2011).

There has been a growing interest in microalgae as a source of metabolites to obtain new drugs through extraction with different organic solvents and subsequent purification for different purposes (SHIMIZU, 2003). As regards fungal inhibition, Tantawy (2011) and Abedin and Taha (2008) demonstrated the inhibitory effect of Spirulina platensis, Anabaena oryzae, Tolypotrix ceytonica, Chlorella pyrenoidosa, and Scenedesmus quadricauda extracts in acetone or methanol against the development of Fusarium moniliforme with promising results for the prevention of fungal contamination.

However, there are no reports in the existing literature the inhibition mechanism of phenolic compounds against

Received 3/8/2012

Accepted 9/10/2012 (00Q5824)

Laboratório de Ciência de Alimentos, Escola de Química e Alimentos, Universidade Federal do Rio Grande - FURG, Engenheiro Alfredo Huch, 475, CP 474, CEP 96201-900, Rio Grande, RS, Brasil, e-mail: nandapagnu@terra.com.br

${ }^{2}$ Laboratório de Epidemiologia de Plantas, Faculdade de Agronomia, Universidade Federal do Rio Grande do Sul - UFRGS, Av. Bento Gonçalves, 7712, CEP 91540-000, Porto Alegre, RS, Brasil

*Corresponding author 
Fusarium graminearum. Therefore, further investigations into the behaviour of various toxigenic species in the presence of natural fungicides are important since such knowledge could support the use of these fungicides focusing on food safety.

In order to reduce the multiplication of fungal biomass, inhibitory compounds act on the primary metabolism of nutrient production reactions, production of membranes or cell walls, respiratory activity, and cell differentiation (CASTRO et al., 2004). These development difficulties can lead to the production of secondary metabolites such as micotoxins, for instance, as the defence against growth medium stress (OLIVEIRA; BADIALE-FURLONG, 2008).

Measurement of the zones of inhibition of the colonies, cell wall, membrane constituents (ergosterol and glucosamine), and alterations in enzyme activity with consequent reduced biomolecular synthesis are indicators of the cell multiplication inhibition mechanism. Few of these effects are considered in terms of the production of micotoxins by toxigenic species. Therefore, information on the alteration of these metabolic pathways is fundamental prior to any recommendation or purification of extracts for use in the prevention or inhibition of microbial contamination in the food chain.

This study involved the assessment of the antifungal activity of phenolic compounds extracted from Spirulina SP. LEB-18 on 12 toxigenic strains of Fusarium graminearum, extracted from barley and wheat, through the determination of structural compounds and enzyme activity of the microorganisms' primary metabolism in order to identify the principal metabolic path affected.

\section{Materials and methods}

\subsection{Isolation and growth of Fusarium graminearum species}

The twelve fungal strains used in this study (Table 1) were obtained from the Plant Epidemiology Laboratory (UFRGS) and were isolated from wheat and barley grains grown in Rio Grande do Sul, Brazil, and harvested in 2007/2008. The fungus was identified based on observations of structures such as the

Table 1. Fusarium strains examined.

\begin{tabular}{lccc}
\hline \multicolumn{1}{c}{ Species } & $\begin{array}{c}\text { Strain } \\
\text { code }\end{array}$ & $\begin{array}{c}\text { Host } \\
\text { plant }\end{array}$ & Micotoxin \\
\hline Fusarium graminearum sensu strict & $702-01$ & Wheat & 15 ADON \\
Fusarium graminearum sensu strict & B-10 & Wheat & 15 ADON \\
Fusarium graminearum sensu strict & B-08 & Wheat & 15 ADON \\
Fusarium graminearum sensu strict & C-4 & Wheat & 15 ADON \\
Fusarium graminearum meridionale & $730-10$ & Wheat & NIV \\
Fusarium graminearum meridionale & $702-25$ & Wheat & NIV \\
Fusarium graminearum meridionale & $46 \mathrm{C}-1$ & Barley & NIV \\
Fusarium graminearum meridionale & $14 \mathrm{C}-1$ & Barley & NIV \\
Fusarium graminearum meridionale & $18 \mathrm{C}-2$ & Barley & NIV \\
Fusarium graminearum sensu strict & A-3 & Wheat & 15 ADON \\
Fusarium graminearum meridionale & $39 \mathrm{C}-2$ & Barley & NIV \\
Fusarium graminearum sensu strict & A-6 & Wheat & 15 ADON \\
\hline
\end{tabular}

mycelia and spores under an optical microscope comparing them with literature reports. In addition, chemotaxonomy was performed (ASTOLFI et al., 2010, 2011) for the identification of the toxigenic profile of the microorganism used in the study.

Cultures of fungi were grown on Spezieller Nährstoffarmer Agar (SNA) at $25{ }^{\circ} \mathrm{C}$ to sporulation and maintained at $4{ }^{\circ} \mathrm{C}$ onto SNA slants. All fungal growth experiments were carried out in potato dextrose agar (PDA) for 7 days to obtain discs of mycelial material.

\subsection{Biomass production system and extraction of phenolic compounds}

Spirulina LEB-18 isolated from the Mangueira Lagoon was supplemented with $20 \%$ (v/v) Zarrouk medium, referred to in the text as MLW-S medium, for maintenance, inoculums, and biomass production. The pilot plant for production of Spirulina sp. is located near the shore of the Mangueira Lagoon $\left(33^{\circ} 30^{\prime} 13^{\prime \prime} \mathrm{S}\right.$ and $\left.53^{\circ} 08^{\prime} 59^{\prime \prime} \mathrm{W}\right)$ and consists of raceway tanks of different dimensions and volumes depending on their purpose. All tanks were lined with glass fiber and covered by a greenhouse structure with transparent polyethylene film. They were agitated by a paddle wheel rotating at $18 \mathrm{rpm}, 24$ hours a day. The culture media volume was maintained by periodic addition of MLW to compensate for evaporation; roughly $12 \mathrm{~L} \mathrm{day}^{-1}$ was added over the course of the experiment (MORAIS; COSTA, 2007).

The phenolic compounds were extracted from $6 \mathrm{~g}$ of Spirulina homogenized with $20 \mathrm{~mL}$ of methanol in an orbital shaker (Tecnal, TE-141, Erechim, Brasil) at $25^{\circ} \mathrm{C}$ for 60 minutes at $200 \mathrm{rpm}$. The extract was centrifuged, filtered, and evaporated in a rotary evaporator (Fisatom, 801-802, São Paulo, Brasil) at $50^{\circ} \mathrm{C}$, dissolved in $25 \mathrm{~mL}$ of sterile distilled water and clarified with $5 \mathrm{~mL}$ of $0.1 \mathrm{M}$ barium hydroxide and $5 \mathrm{~mL}$ of $5 \%$ zinc sulfate. The clarified extract was vacuum filtered (Marconi, MA 454, Sao Paulo, SP) with a sterile membrane with pore size of $0.25 \mu \mathrm{m}$.

Phenolic compounds (PC) were quantified by spectrophotometry (Varian, Cary 100, California, USA) using the Folin-Ciocalteau reagent, and their content was determined from a calibration curve of gallic acid with concentrations ranging from 4 to $50 \mu \mathrm{g} \mathrm{mL} L^{-1}$.

\subsection{Antifungal activity}

Food-pathogenic fungi multiplication was tested by the Agar dilution method, in the appropriate culture medium (PDA). The phenolic compounds at different concentrations $(10 \%, 8 \%, 6 \%, 5 \%$, and $3.5 \% \mathrm{p} / \mathrm{p})$ were added to the culture medium at a temperature of $35-40{ }^{\circ} \mathrm{C}$ and poured into Petri dishes $(10 \mathrm{~cm}$ diameter). The moulds were inoculated after medium solidification. A disc (1.1 $\mathrm{mm}$ in diameter) of mycelial material, taken from the edge of seven-day-old fungi cultures, was placed at the centre of each Petri dish. The Petri dish with the inoculums was then incubated at $25^{\circ} \mathrm{C}$ (Quimis, Q216F20M, São Paulo, Brasil). The efficiency of the treatment was evaluated each day for seven days by measuring the diameter of the 
colonised fungus. The values were expressed in millimeters diameter $\mathrm{h}^{-1}$. All tests were performed in quintuplicate.

The daily measurement data of the mycelial growth zone in the control and treatment dishes were adjusted to the logistic model and Gompzert model in order to determine the maximum growth rate and lag phase length (Table 2) (NAKASHIMA; ANDRÉ; FRANCO, 2000; HAMIDI-ESFAHANI et al., 2007). Comparison of the models was made using the correlation coefficient $\left(\mathrm{R}^{2}\right)$.

Fungal development was estimated based on the control group (without phenolic extract for all inhibition indicators assessed in the study). The percentage inhibition of fungal growth was calculated according to Nguefack et al. (2004): Inhibition $=100 \times(($ control - treatment $) /$ control $)$. The median inhibitory concentration $\left(\mathrm{MIC}_{50}\right)$ was considered as the PC concentration that resulted in 50\% inhibition of the fungal growth when compared to the control groups.

On the seventh day, the dishes were frozen and the biomass dried at $60{ }^{\circ} \mathrm{C}$ (Quimis, Q314M242, São Paulo, Brasil) for 3 hours to determine the glucosamine and ergosterol levels. To determine amylase, protease, and lipase activity, the petri dishes were not subjected to the drying process.

\subsection{Glucosamine content}

Glucosamine from dry fungal biomass $(1 \mathrm{~g})$ was extracted with $5 \mathrm{~mL}$ of $\mathrm{HCl} 6 \mathrm{~mol} \mathrm{~L}^{-1}$ at $121{ }^{\circ} \mathrm{C}$ for 20 minutes. The hydrolyzed material was neutralized with $\mathrm{NaOH} 3 \mathrm{M}$, and reverse titration was carried out with $\mathrm{KHSO}_{4}\left(1 \mathrm{~g} 100 \mathrm{~mL}^{-1}\right)$. Finally, the colorimetric method was used for the determination of glucosamine (SOUZA et al., 2011). The absorbance units were obtained by spectrophotometry (Varian, Cary 100, California, EUA) at $530 \mathrm{~nm}$, and the concentrations were established using a standard curve for glucosamine $\left(0.01\right.$ to $\left.0.2 \mathrm{~g} \mathrm{~L}^{-1}\right)$. The measurements were carried out in triplicate, and the results were expressed as glucosamine per mg sample.

\subsection{Ergosterol content}

A modified method of the Gutarowska and Zakowska (2009) technique was used to determine the ergosterol content in the dry biomass, consisting of $0.2 \mathrm{~g}$ of the samples with $10 \mathrm{~mL}$ of methanol agitated in shaker (Tecnal, TE-141, Erechim, Brasil) at $200 \mathrm{rpm}$ for 30 minutes. This procedure was carried out three times. The methanol extract was centrifuged at $3.200 \mathrm{~g}$ at $20^{\circ} \mathrm{C}$ for 10 minutes. Next, it was heated under reflux for 30 minutes and cooled at $4{ }^{\circ} \mathrm{C}$. The refluxed material was submitted to four partitions with $20 \mathrm{~mL}$ hexane. The hexane fraction was dried

Table 2. Parameters of the Logistic and Gompzert models associated to the lag phase length $\left(t_{1}\right)$ and maximum cellular growth rate $\left(\mu_{\max }\right)$.

\begin{tabular}{ll}
\hline \multicolumn{1}{c}{ Logistic } & \multicolumn{1}{c}{ Gompzert } \\
\hline$\mu_{\max }=\left(\mathrm{A}_{\mathrm{A}}{ }^{*} \mathrm{~B}\right) / 4$ & $\mu_{\max }=\left(\mathrm{A}_{\mathrm{A}}{ }^{*} \mathrm{~B}\right) / \mathrm{e}$ \\
$\mathrm{t}_{1}=(\mathrm{D}-2) / \mathrm{B}$ & $\mathrm{t}_{1}=\mathrm{M}-(\mathrm{B} / \mathrm{B})$ \\
\hline
\end{tabular}

A: parameter that describes logarithmic growth of the population, D: parameter associated to cell growth and B: dimensionless parameter. in a rotatory evaporator (Fisatom, 801-802, Erechim, Brasil) at $60{ }^{\circ} \mathrm{C}$. The residue was dissolved with $10 \mathrm{~mL}$ methanol, and transmittance was determined at $283 \mathrm{~nm}$. The ergosterol content was estimated using a calibration curve of standard ergosterol with concentrations ranging from 1.5 to $16.5 \mu \mathrm{g} \mathrm{mL}-1$

\subsection{Enzymatic activity}

The enzyme extract was obtained from the fungal biomass with $20 \mathrm{~mL}$ of $\mathrm{NaCl} 0.9 \%$ in an ultrasonic bath (Unique, USC800A, São Paulo, Brasil) for 40 minutes, centrifuged (Cientec, CT-5000R, São Paulo, Brasil), and filtered. The $\alpha$-amylase activity was determined by starch degradation estimated quantitatively by iodometric titration; protease activity was determined using albumin substrate and tyrosine as hydrolysis indicator (BARAJ; GARDA-BUFFON; BADIALE-FURLONG, 2010), and lipolytic activity was measured by the release of fatty acids during hydrolysis (FEDDERN et al., 2010).

\subsection{Statistical analysis}

Conventional statistical methods were used to calculate means and standard deviations. Data were analyzed statistically by ANOVA for significant differences $(\mathrm{p}<0.05)$. To ascertain significant differences between the levels of the main factor, Tukey's test was applied between means (BARROS NETO; SCARMINIO; RUNS, 2003).

\section{Results and discussion}

Using the data of the multiplication of the 12 fungi tested in the absence of the phenolic extract, different primary models were adjusted to obtain the growth parameters (Table 3): maximum exponential growth rate $\left(\mu_{\max }\right)$ and lag phase length $\left(\mathrm{t}_{1}\right)$.

Both models showed mean variance greater than $97 \%$, and the Gompzert model proved more applicable due to better fit to the experimental results. Therefore, this model was selected to assess the effects of the phenolic extracts on the kinetic parameters of microbial growth (Table 4).

Table 3. Logistic and Gompzert models of the microbial growth curves in the absence of phenolic extract.

\begin{tabular}{llrllll}
\hline \multirow{2}{*}{$\begin{array}{c}\text { Fusarium } \\
\text { graminearum }\end{array}$} & \multicolumn{3}{c}{ Logistic model } & \multicolumn{3}{c}{ Gompzert model } \\
\cline { 2 - 7 } & $\mu \max$ & \multicolumn{1}{c}{$\mathrm{t}_{1}$} & \multicolumn{1}{c}{$\mathrm{R}^{2}$} & $\mu \max$ & \multicolumn{1}{c}{$\mathrm{t}^{\mathrm{d}}$} & $\mathrm{R}^{2}$ \\
\hline $46 \mathrm{C}-1$ & $0.016^{\mathrm{c}}$ & $7.1^{\mathrm{f}}$ & 98.3 & $0.015^{\mathrm{c}}$ & $3.1^{\mathrm{d}}$ & 99.4 \\
$702-01$ & $0.024^{\mathrm{ab}}$ & $6.8^{\mathrm{f}}$ & 98.7 & $0.024^{\mathrm{a}}$ & $4.4^{\mathrm{c}}$ & 99.5 \\
$\mathrm{~B}-10$ & $0.019^{\mathrm{bc}}$ & $19.7^{\mathrm{g}}$ & 99.4 & $0.018^{\mathrm{bc}}$ & $13.3^{\mathrm{fg}}$ & 99.3 \\
$\mathrm{~B}-8$ & $0.016^{\mathrm{c}}$ & $3.8^{\mathrm{b}}$ & 97.6 & $0.016^{\mathrm{c}}$ & $1^{\mathrm{e}}$ & 98.4 \\
$\mathrm{C}-4$ & $0.025^{\mathrm{a}}$ & $19.4^{\mathrm{g}}$ & 99.7 & $0.023^{\mathrm{ab}}$ & $14.7^{\mathrm{a}}$ & 99.7 \\
$14 \mathrm{C}-1$ & $0.017^{\mathrm{c}}$ & $17.4^{\mathrm{c}}$ & 99.3 & $0.016^{\mathrm{abc}}$ & $10.6^{\mathrm{h}}$ & 99.4 \\
$730-10$ & $0.020^{\mathrm{abc}}$ & $17.9^{\mathrm{c}}$ & 99.5 & $0.019^{\mathrm{abc}}$ & $12.8^{\mathrm{g}}$ & 99.8 \\
$702-25$ & $0.018^{\mathrm{c}}$ & $19.7^{\mathrm{f}}$ & 99.5 & $0.017^{\mathrm{c}}$ & $13.6^{\mathrm{f}}$ & 99.7 \\
$18 \mathrm{C}-2$ & $0.020^{\mathrm{abc}}$ & $12.8^{\mathrm{e}}$ & 99.2 & $0.019^{\mathrm{abc}}$ & $8^{\mathrm{i}}$ & 99.6 \\
$\mathrm{~A}-3$ & $0.018^{\mathrm{c}}$ & $15.9^{\mathrm{a}}$ & 99.2 & $0.017^{\mathrm{c}}$ & $10.9^{\mathrm{h}}$ & 99.8 \\
$39 \mathrm{C}-2$ & $0.015^{\mathrm{c}}$ & $13.4^{\mathrm{d}}$ & 98.9 & $0.014^{\mathrm{c}}$ & $8.5^{\mathrm{i}}$ & 99.7 \\
A-6 & $0.016^{\mathrm{c}}$ & $12.9^{\mathrm{de}}$ & 98.7 & $0.016^{\mathrm{c}}$ & $9.3^{\mathrm{b}}$ & 99.6 \\
\hline
\end{tabular}


The twelve fungi assayed showed a growth latent period that ranged from 1 to 14.7 hours for microorganisms B-8 and $\mathrm{C}-4$ in the control media. Under the same conditions, the exponential growth rate varied from 0.014 to $0.024 \mathrm{~h}^{-1}$ (Table 3 ). In the medium containing growing concentrations of $\mathrm{PE}$, the microorganisms grew at slower rates, inversely proportional to the concentration level. Therefore, the phenolic extracts reduced the growth rate of the Fusarium toxigenic species studied (Tables 3 and 4).

When the culture medium with $10 \% \mathrm{PE}(\mathrm{p} / \mathrm{p})$ was used, a slower lag phase was observed since, on average, the microbial development first became apparent 50 hours after incubation, indicating the fungistatic effect of the $\mathrm{PE}$, especially for the $F$. graminearum species 702-01, 702-25, 46C-1, 14C-1, and 18C2. However, when the $\mathrm{PE}$ concentration reached $10 \%$ in the culture medium, its mycelial growth rates reduced to $0.7,0.9$, and $0.8 \mathrm{~mm} \mathrm{~h}^{-1}$. Figure 1 illustrates the behaviour of the most susceptible fungal species towards the effect of the active agent.

The $\mathrm{IC}_{50}$ values found for species 702-01, B-10, C-4, 702-25, $46 \mathrm{C}-1$, and $18 \mathrm{C}-2$ and A- 3 were obtained with $3 \%$ concentration
(444 $\mu \mathrm{g})$; concentration of $4 \%(600 \mu \mathrm{g})$ was required for the microorganisms B-8, 730-10, and 14C-1 and $8 \%$ concentration $(1990 \mu \mathrm{g})$ for 39C-2 and A-6. This fact shows the variable resistance of the species assayed to the same active agent.

The inhibition results obtained in this study are consistent with those found by other authors who have studied Spirulina platensis cultivated under other conditions, which was more efficient than other cyanobacteria (Anabaena oryzae and Tolypotrix ceytonica) and green microalgae (Chlorella pyrenoidosa and Scenedesmus quadricauda) (ABEDIN; TAHA, 2008). Tantawy (2011) also assessed the antifungal potential of some microalgae, and the results with Spirulina platensis extracts were effective to inhibit Fusarium oxysporum. It is worth mentioning that the greatest inhibition obtained by these authors was approximately 60\%, whereas in this study, the inhibition results were approximately $90 \%$.

The percentages of mycelial growth inhibition in all of the species tested, with values ranging from $50 \%$ to $90 \%$, can be attributed to the fact that the phenolic extract is acting on the mycelium hyphae causing discharge of cytoplasmic components,

Table 4. Maximum growth rate of fungi treated with different concentrations of phenolic extract.

\begin{tabular}{llllll}
\hline \multirow{2}{*}{$\begin{array}{c}\text { Fusarium } \\
\text { graminearum }\end{array}$} & \multicolumn{5}{c}{$\mu$ max $\left(\mathrm{h}^{-1}\right)$} \\
\cline { 2 - 6 } & \multicolumn{1}{c}{$10 \%$} & \multicolumn{5}{c}{ Phenolic extract } \\
\cline { 2 - 6 } & $0.003^{\mathrm{Ac}}(96.8)$ & $0.005^{\mathrm{Ac}}(98.6)$ & $0.006^{\mathrm{Ac}}(99.6)$ & $0.006^{\mathrm{Ac}}(98.9)$ & $0.005^{\mathrm{Aa}}(97.0)$ \\
$76 \mathrm{C}-1$ & $0.007^{\mathrm{Babc}}(84.5)$ & $0.006^{\mathrm{Bcd}}(96.0)$ & $0.013^{\mathrm{Aab}}(96.2)$ & $0.010^{\mathrm{Abc}}(95.9)$ & $0.011^{\mathrm{Ab}}(94.0)$ \\
702-01 & $0.006^{\mathrm{Bbc}}(95.5)$ & $0.013^{\mathrm{Aa}}(96.9)$ & $0.008^{\mathrm{ABab}}(95.2)$ & $0.006^{\mathrm{Bc}}(95.7)$ & $0.011^{\mathrm{ABb}}(94.7)$ \\
$\mathrm{B}-10$ & $0.006^{\mathrm{ABbc}}(94.1)$ & $0.014^{\mathrm{Aa}}(97.0)$ & $0.008^{\mathrm{Bbc}}(96.2)$ & $0.009^{\mathrm{Bbc}}(96.7)$ & $0.010^{\mathrm{Bab}}(97.6)$ \\
$\mathrm{B}-8$ & $0.003^{\mathrm{Bc}}(97.6)$ & $0.005^{\mathrm{Bd}}(98.2)$ & $0.008^{\mathrm{ABbc}}(98.9)$ & $0.011^{\mathrm{Abc}}(95.9)$ & $0.011^{\mathrm{Ab}}(99.6)$ \\
$\mathrm{C}-4$ & $0.008^{\mathrm{Aabc}}(99.7)$ & $0.010^{\mathrm{Aabcd}}(99.8)$ & $0.013^{\mathrm{Aab}}(99.0)$ & $0.012^{\mathrm{Aab}}(99.5)$ & $0.012^{\mathrm{Ab}}(99.5)$ \\
$14 \mathrm{C}-1$ & $0.012^{\mathrm{Aa}}(99.0)$ & $0.011^{\mathrm{Aabc}}(99.6)$ & $0.010^{\mathrm{Aabc}}(99.6)$ & $0.011^{\mathrm{Abc}}(97.8)$ & $0.012^{\mathrm{Ab}}(99.4)$ \\
$730-10$ & $0.009^{\mathrm{Abc}}(99.3)$ & $0.007^{\mathrm{Abcd}}(97.7)$ & $0.008^{\mathrm{Abc}}(98.3)$ & $0.008^{\mathrm{Abc}}(98.8)$ & $0.010^{\mathrm{Aab}}(99.8)$ \\
$702-25$ & $0.006^{\mathrm{Abc}}(98.7)$ & $0.007^{\mathrm{Abcd}}(99.3)$ & $0.010^{\mathrm{Abcd}}(99.2)$ & $0.009^{\mathrm{Abc}}(82.3)$ & $0.011^{\mathrm{Ab}}(98.9)$ \\
$18 \mathrm{C}-2$ & $0.004^{\mathrm{Abc}}(99.1)$ & $0.006^{\mathrm{Acd}}(98.2)$ & $0.007^{\mathrm{Ac}}(98.3)$ & $0.009^{\mathrm{Abc}}(99.5)$ & $0.009^{\mathrm{Aab}}(99.7)$ \\
$\mathrm{A}-3$ & $0.012^{\mathrm{Aa}}(95.3)$ & $0.009^{\mathrm{Aabcd}}(99.8)$ & $0.011^{\mathrm{Aabc}}(99.9)$ & $0.011^{\mathrm{Abc}}(98.4)$ & $0.014^{\mathrm{Ab}}(99.7)$ \\
$39 \mathrm{C}-2$ & $0.012^{\mathrm{Aa}}(99.3)$ & $0.012^{\mathrm{Aab}}(98.6)$ & $0.014^{\mathrm{Aa}}(99.5)$ & $0.017^{\mathrm{Aa}}(99.7)$ & $0.014^{\mathrm{Ab}}(99.3)$ \\
$\mathrm{A}-6$ & &
\end{tabular}

Results relative to $\mu_{\max }$ were estimated according to Gompzert model. Values are expressed as means $\left(\mathrm{R}^{2}\right)$. Same lower case letters in the same column mean non-significant differences between the means at 95\% confidence. Same capital letters in the same line mean non-significant differences between the means at $95 \%$ confidence.
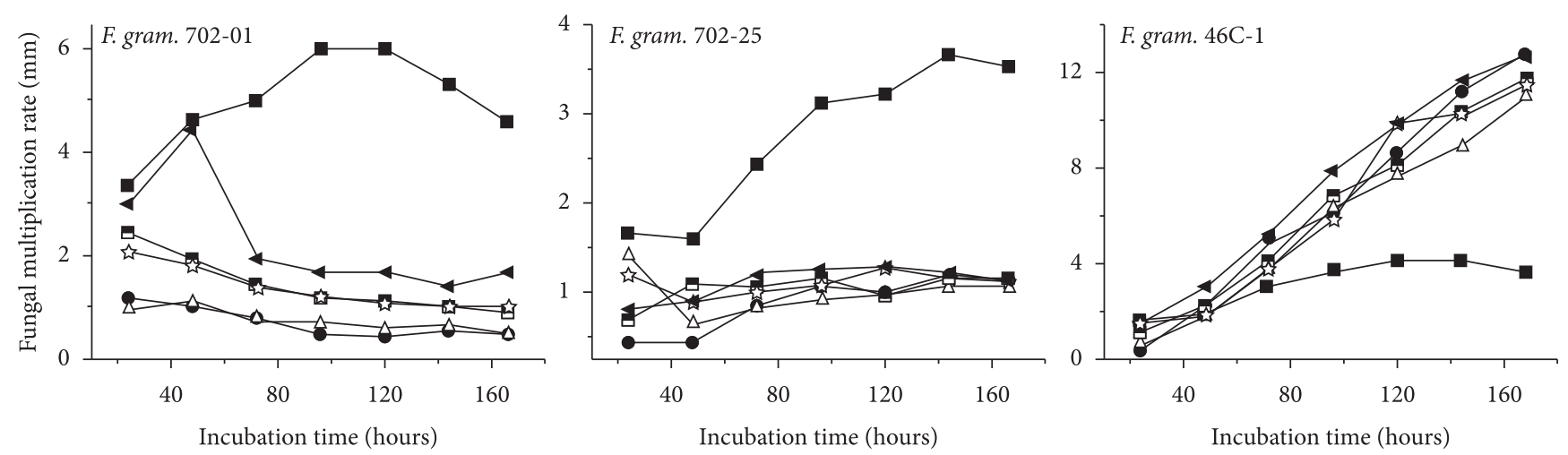

Figure 1. Fungi growth curves for Fusarium graminearum ( $\rightarrow-)$ treated with phenolic extracts at concentration $10 \%(-\bullet), 8 \%(\neg-), 6 \%$ $(\neg), 5 \%(\neg-)$, and $3.5 \%(-4)$. 
Table 5. Percentage (\%) of the fungal growth inhibition indicators.

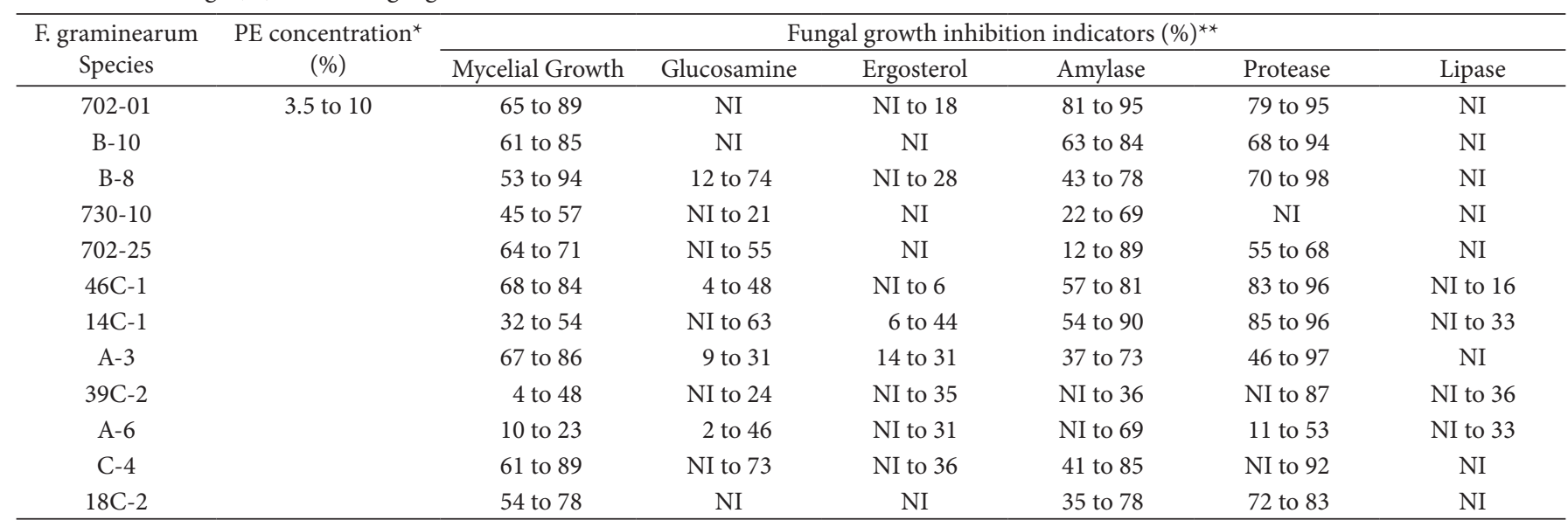

${ }^{*}$ Phenolic extract (PE) concentration: $10,8,6,5$ and $3.5 \%$. ${ }^{* *}$ Results relative to lowest and highest inhibition percentage after 7 th day of experiment.

loss of rigidity, and integrity of the hypha resulting in the collapse and death of the mycelium, similar to that reported by Sharma and Tripathi (2006).

Such possibility is suggested by the inhibition of amylase activity (95\%) of the F. graminearum 702-01 stock isolated from wheat. This results from the inhibition of the interaction between amylase and the substrate available in the culture medium by PE components hindering the the production of the energy required to form the structures needed to maintain cellular viability (Table 2).

The protease inhibition values reached $98 \%$ for the species F. graminearum 702-01 and B-8, which were also isolated from wheat. Among the species isolated from barley is $F$. graminearum 14C-1, whose proteolytic activity was inhibited by $96 \%$ (Table 2), which also hinders the structural organization of the microbial cell.

Phenolic compounds are also capable of inhibiting amino acid synthesis by hindering the reaction between phosphoenolpyruvate and erythrose-4-phosphate and producing shikimic acid, which results in the production of tryptophan and prevents the production of phenylalanine or tyrosine through the prephenic acid pathway (CASTRO et al., 2004). Therefore, if the use of raw phenolic extract from Spirulina sp. exhibited promising growth inhibitory profile, the data show that this results from the inactivation of the enzymatic systems of Fusarium graminearum.

These extracts may have acted as direct inhibitors of the catalysis of the affected enzymes or have prevented their synthesis due to the lack of important amino acids for the constitution of the protein chain.

Although the glucosamine content was lower than that in the PE-treated biomass, this was not the most heavily affected component during inhibition of fungal multiplication. In B-8, 730-10, 46C-1 and 39C-2 species, there was reduced production under $\mathrm{PE}$ concentrations greater than $8 \%(\mathrm{p} / \mathrm{p})$; whereas in 702 $25, \mathrm{C}-4,14 \mathrm{C}-1$, and A-6, inhibition was obtained using lower phenolic extract concentrations ( $5 \%$ and $3.5 \% \mathrm{p} / \mathrm{p}$ ). Again, the variation in the susceptibility of each strain to the effects of the PE is evidenced (Table 5).

The ergosterol content and lipolytic activity were not significantly affected by the PE (Table 2). According to Aragão et al. (2009), microorganisms synthesise extracellular enzymes such as lipase to subsequently produce their triglycerides and other metabolic lipids. In this case, the non-reduction in the ergosterol synthesis pathway and in the lipase activity suggest that the fungi used the fatty acids of the microalgae that can be in the PE (COLLA et al., 2007) for the synthesis of endogenous lipids, thus maintaining the stability of the functions that depend on them. This is a very promising finding since micotoxin synthesis is triggered by the alteration of the metabolic pathway for the production of fatty acids and their byproducts.

\section{Conclusions}

Phenolic compounds extracted from Spirulina sp. LEB18 showed promising antifungal activity against Fusarium graminearum strains when applied to the culture medium at concentrations ranging from $3 \%$ to $8 \%(\mathrm{p} / \mathrm{p})$ to reach $\mathrm{IC}_{50}$.

Parallel to this inhibition, there was a six to seven-fold reduction (on average) in amylase and protease activity in the fungal biomass compared to that of the control groups. The other metabolic activity indicators showed negligible changes.

\section{Ackonwledgements}

The authors are grateful to the Nanofothobiotec network.

\section{References}

ABEDIN, R. M. A.; TAHA, H. M. Antibacterial and antifungal activity of cyanobacteria and Green microalgae. Evaluation of medium components by Plackett-Burman design for antimicrobial activity of Spirulina platensis. Global Journal of Biotechnology and Biochemistry, v. 3, n. 1, p. 22-31, 2008.

ARAGÃO, V. C. et al. Síntese enzimática de butirato de isoamila empregando lipases microbianas comerciais. Química Nova, 
v. 32 , p. $2268-2272,2009$. http://dx.doi.org/10.1590/S010040422009000900005

ASTOLFI, P. et al. Complexo Fusarium graminearum: Taxonomia, potencial toxigênico e genética populacional na era molecular. Revista Anual de Patología de Plantas, v. 18, p. 78-119, 2010.

ASTOLFI, P. et al. Moleculart survey of trichothecene genotypes of Fusarium graminearum species complex from barley in Southern Brazil. International Journal of Food Microbiology, v. 148, p. 197-201, 2011. PMid:21665312.

BARAJ, E.; GARDA-BUFFON, J.; BADIALE-FURLONG, E. Influence of the trichothecenes DON and T-2 toxin in malt aminolitic enzymes activity. Brazilian Journal of Food Technology, v. 53, p. 14, 2010.

BARROS NETO, B.; SCARMINIO, I. S.; BRUNS, R. E. Como fazer experimentos. Campinas: Editora da Unicamp, 2003.

CASTRO, H. G. et al. Contribuição ao estudo das plantas medicinais: Metabólitos secundários. 2. ed. Visconde do Rio Branco, 2004.

COLLA, L. M. et al. Production of biomass, lipids, phenolic compounds and proteins by Spirulina platensis under different temperature and nitrogen regimes. Bioresource Technology, v. 98, p. 1489-1493, 2007. PMid:17070035. http://dx.doi.org/10.1016/j. biortech.2005.09.030

DORS, G. C. et al. Distribution of pesticides in rice grain and rice bran. Journal of the Brazilian Chemical Society, v. 22, p. 1921-1930, 2011. http://dx.doi.org/10.1590/S0103-50532011001000013

FEDDERN, V. et al. Physico-chemical composition, fractionated glycerides and fatty acid profile of chicken skin fat. European Journal of Lipid Science and Technology, v. 112, p. 1277-1284, 2010. http:// dx.doi.org/10.1002/ejlt.201000072

GUTAROWSKA, B.; ZAKOWSKA, Z. Mathematical models of myceliul growth and ergosterol synthesis in stationary mould culture. Letters in Applied Microbiology, v. 48, p. 605-610, 2009. PMid:19291213. http://dx.doi.org/10.1111/j.1472-765X.2009.02577.x

HAMIDI-ESFAHANI, Z. et al. A two-phase kinetic model for fungal growth in solid-state cultivation. Biochemical Engineering Journal, v. 36, p. 100-107, 2007. http://dx.doi.org/10.1016/j.bej.2007.02.005

HEIDTMANN-BEMVENUTI, R. et al. Determinação de deoxinivalenol e zearalenona em arroz natural e parboilizado e suas frações utilizando QuEChERS e HPLC/UV-FL. Química Nova, v. 35, n. 6, p. 1-6, 2012. http://dx.doi.org/10.1590/S0100-40422012000600033

MORAIS, M. G.; COSTA, J. A. V. Isolation and selection of microalgae from coal fired thermoelectric power plant for biofixation of carbon dioxide. Energy Conversion and management, v. 48, p. 2169-2173, 2007. http://dx.doi.org/10.1016/j. enconman.2006.12.011

NAKASHIMA, S. M. K.; ANDRÉ, C. D. S.; FRANCO, B. D. G. M. Aspectos básicos da microbiologia preditiva. Brazilian Journal of Food Technology, v. 3, p. 41-51, 2000.

NGUEFACK, J. et al. Evaluation of five essential oils from aromatic plants of Cameroon for controlling food spoilage and mycotoxin producing fungi. International Journal of Food Microbiology, v. 94, p. 329-334, 2004. PMid:15246244. http://dx.doi.org/10.1016/j. ijfoodmicro.2004.02.017

OLIVEIRA, M. S.; BADIALE-FURLONG, E. Screening of antifungal and antimycotoxigenic acitivity of plant phenolic extracts. World Mycotoxin Journal, v.1, n. 2, p. 139-146, 2008. http://dx.doi. org/10.3920/WMJ2008.1006

PAGNUSSATT, F. A. et al. Extraction of fungal amylase inhibitors from cereal using response surface methodology. International Research Journal Agricultural Science and Soil Science, v. 1, p. 428-434, 2012.

SHARMA, N.; TRIPATHI, A. Effects of Citrus sinensis (L.) Osbeck Epecarp essential oil on growth and morphogenesis of Aspergillus niger (L.) VanTieghem. Microbiological Research, 2006.

SHIMIZU, Y. Microalgal metabolites. Current Opinion in Microbiology, v. 6, p. 236-242, 2003. http://dx.doi.org/10.1016/ S1369-5274(03)00064-X

SOUZA, M. M. et al. Assesment of the antifungal activity of Spirulina platensis phenolic extract against Aspergillus flavus. Ciência e Agrotecnologia, v. 35, p. 1050-1058, 2011

TANTAWY, S. T. A. Biological potential of cyanobacteria metabolites against some soil pathogenic fungi. Journal of Food, Agriculture and Environment, v. 9, n. 1, p. 663-666, 2011.

VIUDA-MARTOS, Y. et al. Antifungal activity of lemon (Citrus lemon L.), mandarin (Citrus reticulata L.), grapefruit (Citrus paradisi L.) and orange (Citrus sinensis L.) essential oils. Food Control, v. 19, p. 1130-1138, 2008. http://dx.doi.org/10.1016/j. foodcont.2007.12.003

ZABKA, M.; PAVELA, R.; GABRIELOVA-SLEZAKOVA, L. Promissing anrtifungal effect of some Euro-Asiatic plants against dangerous pathogenic and toxigenic fungi. Journal of Science and Food Agriculture, v. 91, p. 492-497, 2011. PMid:21218483. http://dx.doi. org/10.1002/jsfa.4211 